Jurnal Civic Education, Vol. 1 No. 2 Desember 2017

\title{
PENYIMPANGAN TERHADAP ASAS NON-RETROAKTIF DALAM \\ PERKARA PELANGGARAN HAM BERAT
}

\author{
Hendra Rawung
}

Dosen Program Studi Ilmu Hukum FIS UNIMA

\begin{abstract}
Indonesia has been criticized by the international community, especially the many actors who are considered responsible for some particularly of the gross violation of human rights that occurred in the past are allowed to live free from prosecution. With regard to the occurrence of the gross violations of human rights in the past there is a legal breakthrough in an effort to uncover and resolve cases the gross violations of human rights, namely the demise of a provision enacted criminal known as retroactive. It is stipulated in Article 43 Paragraph (1) Law No. 26 of 2000 concerning Human Rights Court. Efforts to impose a retroactive principle on one hand has been controversial because it is considered contrary to the principle of non retroactivity which is a manifestation of the principle of legality, which in principle is a provision that prohibits the enactment of the statute retroactively. But the other side of the principle of non retroactivity is also considered to be protecting the perpetrators to be free from prosecution and sentencing.
\end{abstract}

Kata Kunci: Penyimpangan, Asas, Non-Retroaktif, Pelanggaran, HAM. 


\section{A. Pendahuluan}

Mengacu pada sejumlah instrumen yuridis baik internasional maupun nasional, setiap negara memiliki kewajiban yang diembankan untuk mengadakan penuntutan terhadap tiap pelaku pelanggaran HAM berat. Apalagi, kejahatan-kejahatan hak asasi manusia yang terjadi di masa lalu itu memiliki karakter jus cogens, yang membawa implikasi legal bagi negara untuk menghukum pelakunya sebagai kewajiban negara terhadap masyarakat internasional secara keseluruhan (obligatio erga omnes). ${ }^{2}$

Begitu pula yang berlaku di Indonesia, tidak ada pengecualian baik itu dari kalangan sipil, polisi maupun militer yang kebal terhadap hukum, semua harus tetap tunduk terhadap ketentuan hukum. Ketika ada indikasi terjadinya pelanggaran HAM, proses peradilan terhadap pelaku pelanggaran HAM harus dilakukan karena tidak boleh melestarikan impunity yang sudah dinikmati puluhan tahun dan ini penting sebagai pembelajaran sejarah di masa depan. ${ }^{3}$ Namun demikian, kendati perlindungan terhadap HAM di Indonesia dalam konsepnya sebagai hukum positif telah tertuang dalam sejumlah peraturan perundang-undangan, akan tetapi pada tataran implementasinya penerimaan terhadap prinsip-prinsip universalitas HAM masih terkendala. ${ }^{4}$

Banyak diantara individu-individu yang bertanggung jawab atas beberapa kasus

2 Ifdhal Kasim, "Jalan Ketiga" bagi Penyelesaian Pelanggaran Hak Asasi Manusia di Masa Lalu, dalam, Ifdhal Kasim, et, al, Pencarian Keadilan di Masa Transisi, http://www.elsam.or.id/downloads/1296551052_Pen carian_Keadilan_di_Masa_Transisi.pdf, hlm. 6.

${ }^{3}$ Todung Mulya Lubis, Jalan Panjang Hak Asasi Manusia, Gramedia Pustaka, Jakarta, 2005, hlm.13.

Konsep universalitas HAM menunjukkan bahwa HAM adalah norma perilaku yang diterima di seluruh dunia, lihat lebih lanjut dalam Geoffrey Robertson Q.C., Kejahatan Terhadap Kemanusiaan: Perjuangan Untuk Mewujudkan Keadilan Global, Komnas HAM, Jakarta, 2002, hlm. 545-549. pelanggaran HAM berat dibiarkan hidup bebas dari tuntutan hukum sehingga kepada mereka sering diistilahkan dengan "the untouchable", bahkan ada yang tetap sebagai warga masyarakat yang terhormat. ${ }^{5}$ Hal ini menimbulkan anggapan bahwa kekerasan dan pembiaran oleh negara pada beberapa kasus tersebut terjadi karena aparat TNI, Polri dan Intelijen masih menjadi alat kekuasaan, bukan alat negara. ${ }^{6}$

Bila permasalahan (pelanggaran HAM berat) dimasa lalu tidak segera dicarikan solusi dan mekanisme penyelesaiannya, dikhawatirkan segregasi sosial dimasyarakat, akibat stigmatisasi warisan rezim otoriter, menjadi terus berkepanjangan, yang sewaktu-waktu bisa menyulut konflik horisontal, dikemudian hari. Hal ini mengingat begitu banyaknya kasus pelanggaran HAM di masa lalu dan mewariskan bermacam stigma dan predikat bagi para korbannya, tanpa ada kejelasan kapan semua itu akan diakhiri. $^{7}$

Berkenaan dengan peristiwa pelanggaran HAM berat dimasa lalu khususnya sebelum berlakunya undang-undang yang mengatur tentang pengadilan HAM, ada upaya untuk mengungkap dan menyelesaikannya yakni dengan menerapkan hukum berkekuatan surut (retroaktif). Hal ini sangat dimungkinkan penyelenggaraannya sebagaimana yang diatur dalam ketentuan Pasal 43 Ayat (1) UU No. 26 Tahun 2000 tentang Pengadilan HAM, yang menyatakan "Pelanggaran hak asasi manusia

5 Usman Hamid, et.al, Menatap Wajah Korban, Upaya Mendorong Penyelesaian Hukum Kejahatan Terhadap Kemanusiaan dalam Peristiwa Kerusuhan Mei 1998, TIFA, Jakarta, 2005, hlm. 40.

6 Kompas, Kasus Talangsari 22 Tahun Menggantung, 8 Februari 2011, hlm 3.

${ }^{7}$ ELSAM, Mendorong Pembentukan Kembali UU Komisi Kebenaran dan Rekonsiliasi: Pandangan ELSAM Mengenai Pentingnya RUU Komisi Kebenaran dan Rekonsiliasi, http://www.elsam.or.id/downloads/1301382601_Bri ef_Paper_Mendorong_Pembentukan_Kembali_UU_ KKR.pdf, hlm. 2. 
yang berat yang terjadi sebelum diundangkannya Undang-undang ini, diperiksa dan diputus oleh Pengadilan HAM ad hoc." Begitupula dengan Penjelasan Pasal 4 UU No. 39 Tahun 1999, yang menyebutkan: "...Hak untuk tidak dituntut atas dasar hukum yang berlaku surut dapat dikecualikan dalam hal pelanggaran berat terhadap hak asasi manusia yang digolongkan kedalam kejahatan terhadap kemanusiaan".

Ketentuan Pasal 43 Ayat (1) UU No. 26 Tahun 2000 yang secara implisit menyimpangi asas non-retroaktif dipandang oleh sebagian kalangan melanggar ketentuan Pasal 28I Ayat (1) UUD 1945 hasil amandemen kedua, yang secara lengkapnya menyebutkan:

"Hak untuk hidup, hak untuk tidak disiksa, hak kemerdekaan pikiran dan hati nurani, hak beragama, hak untuk tidak diperbudak, hak untuk diakui sebagai pribadi dihadapan hukum, dan hak untuk tidak dituntut atas dasar hukum yang berlaku surut adalah hak asasi manusia yang tidak dapat dikurangi dalam keadaan apa pun."

Dalam hukum pidana adanya penyimpangan terhadap asas non-retroaktif menimbulkan kontroversi karena dianggap bertentangan dengan Pasal 1 Ayat (1) KUHP, yang berbunyi "tiada suatu perbuatan yang dapat dipidana sebelum ada undang-undang yang mengatur tentang suatu perbuatan tersebut". Ketentuan ini merupakan manifestasai dari asas legalitas sebagai sendi utama hukum pidana yang menolak diberlakukannya hukum secara surut. ${ }^{8}$

Asas non-retroaktif, selain diakui dalam hukum nasional juga tertuang dalam beberapa hukum internasional diantaranya, Pasal 11 Universal Declaration of Human Rights (UDHR) 1948, Pasal 15 Ayat (1) International Convention on Civil and Political Rights (ICCPR) 1966, serta Pasal 11 Ayat (1) dan Pasal

8 Mahrus Ali dan Syarif Nurhidayat, Penyelesaian Pelanggaran HAM Berat: In Court System \& Out Court System, Gramata Publishing, Jakarta, 2011, hlm. 63.
22 Ayat (1) International Criminal Court (ICC) 1998.

Akan tetapi meskipun telah ditentukan adanya larangan hukum berlaku surut bukan berarti tidak ada pembatasan atau pengecualian terhadapnya. Pengecualian terhadap asas nonretroaktif tetap diperkenankan apabila dibenarkan oleh hukum internasional, diantaranya Pasal 15 Ayat (2) ICCPR yang secara jelas menentukan pembatasan terhadap asas ini. Praktek hukum internasional juga menunjukkan bahwa terhadap pelanggaran HAM berat dapat dibenarkan menerapkan hukum secara surut. ${ }^{9}$

Beberapa peradilan internasional yang mempraktekkan berlakunya hukum secara retroaktif yaitu, International Military Tribunal (IMT) Nuremberg 1945, International Military Tribunal for the Far East (IMTFE) Tokyo 1946, International Court Tribunal for Yugoslavia (ICTY) 1993, dan International Court Tribunal for Rwanda (ICTR) 1994. ${ }^{10}$

Selain diterapkan pada Tribunal Ad Hoc tersebut di atas, hukum berlaku surut dipraktekkan juga dalam beberapa Mahkamah Pidana Ad Hoc lainnya, kendatipun dengan mekanisme yang berbeda yakni model pengadilan campuran (hybrid court). Terdapat beberapa mahkamah yang menggunakan model seperti ini, yaitu: the Special Panels for Serious Crimes di Timor-Leste, the "Regulation 64 Panels" di Kosovo, the War Crimes Chamber in the Court of Bosnia and Herzegovina, the Special Court for Sierra Leone, serta the Extraordinary Chambers di Kamboja. ${ }^{11}$

9 Bagir Manan, et.al., Perkembangan Pemikiran dan Pengaturan Hak Asasi Manusia di Indonesia, Alumni, Bandung, 2006, hlm. 128; Adnan Buyung Nasution dan A. Patra M. Zen, Instrumen Internasional Pokok Hak Asasi Manusia, Yayasan Obor Indonesia, Jakarta, 2006, hlm. 101.

10 Romli Atmasasmita, Pengantar Hukum Pidana Internasional Bagian II, Hecca Mitra Utama, Jakarta, 2004, hlm 56.

${ }^{11}$ Lihat Indria Fernida, Hak Asasi Manusia, Akuntabilitas dan Penegakan Hukum di Indonesia: Sebuah Toolkit, Insitute for Defense, Security and Peace Studies Press, Jakarta, 2009, melalui, 
Berlakunya UU No. 39 Tahun 1999 dan UU No. 26 Tahun 2000 tidak terlepas dari peristiwa yang melatarbelakangi pembentukannya, dimana dalam peristiwa Timor-Timur (Tim-Tim) pasca jajak pendapat tahun 1999 dipandang oleh komunitas internasional telah terjadi berbagai bentuk kejahatan terhadap kemanusiaan. Desakan internasional melalui Dewan Keamanan Perserikatan Bangsa-Bangsa (DK PBB) untuk membentuk Mahkamah Ad Hoc seperti halnya ICTY dan ICTR, berhasil digagalkan oleh pemerintah Indonesia. Hal ini karena pemerintah Indonesia menyatakan masih mampu untuk mengadili sendiri pelakunya berdasarkan hukum nasional Indonesia. Atas dasar itu, membawa konsekuensi bagi pemerintah Indonesia untuk mengeluarkan UU No. 39 Tahun 1999 dan UU No. 26 Tahun $2000 .^{12}$

Kedua undang-undang tersebut masingmasing ditetapkan dan diundangkan pada tanggal 23 September 1999 dan 23 November 2000, yang selanjutnya dibentuk Pengadilan HAM Ad Hoc dengan menerapkan undangundang tersebut terhadap mereka yang didakwa sebagai pelaku pelanggaran HAM berat dalam kasus di Tim-Tim. Dilihat dari waktu mulai berlaku dan penerapannya, yaitu terhadap peristiwa pelanggaran yang terjadi sebelum mulai berlakunya kedua undang-undang ini, maka tampak dengan jelas telah menyimpangi asas non-retroaktif di dalam prakteknya. ${ }^{13}$

Penyimpangan terhadap asas nonretroaktif masih menimbulkan pandangan pro dan kontra, utamanya dari pihak pelaku dan (keluarga) korban. Kalangan yang menolak dikesampingkannya asas non-retroaktif, didasari atas pandangan bahwa ini bertentangan dengan asas primaritas dalam hukum pidana yaitu asas

http://www.dcaf.ch/content/download/35686/526589 /file/8.\%20Human\%20Rights $\% 20$ and $\% 20$ SSR.pdf, hlm. 7-8.

12 I Wayan Parthiana, Hukum Pidana Internasional dan Ekstradisi, Yrama Widya, Bandung, 2004, hlm. 96.

${ }^{13}$ Ibid, hlm. 115. legalitas. Sedangkan yang mendukung disimpanginya asas non-retroaktif didasarkan, karena hukum pidana sebagai hukum positif belum dapat menjangkau kejahatan yang dikategorikan sebagai pelanggaran HAM berat. Karenanya tulisan ini dimaksudkan untuk mengetahui dan memahami tentang isu hukum penyimpangan terhadap asas non-retroaktif dalam perkara pelanggaran HAM berat ditinjau menurut Hukum Internasional dan Hukum Nasional Indonesia.

\section{B. Pembahasan \\ 1. Landasan Teori}

Sebelum masuk pada asas retroaktif itu sendiri, harus dipahami terlebih dahulu apa yang dimaksud dengan Hak Asasi Manusia (HAM). Dalam Pasal 1 angka 1 UU No. 39 Tahun 1999, ditegaskan bahwa Hak Asasi Manusia adalah seperangkat hak yang melekat pada hakikat dan keberadaan manusia sebagai mahluk Tuhan Yang Maha Esa dan merupakan anugerah-Nya yang wajib dihormati, dijunjung tinggi dan dilindungi oleh negara hukum, Pemerintahan, dan setiap orang demi kehormatan serta perlindungan harkat dan martabat manusia.

Pengakuan dan jaminan perlindungan terhadap hak asasi manusia di Indonesia pada dasarnya telah terkandung dalam nilai-nilai Pancasila, maupun Undang-Undang Dasar 1945, serta perundang-undangan lainnya. Bahwa HAM di Indonesia yang didasarkan pada Pancasila dan UUD 1945 bersifat enlightened tentang manusia, sebagaimana dinyatakan oleh Jacques Maritain dalam tulisannya The Right of Man, yaitu hak-hak yang dipunyai oleh seseorang karena fakta ia adalah manusia. ${ }^{14}$ Menurut Franz Magnis-Suseno sebenarnya hak asasi manusia merupakan pengejawantahan seluruh Pancasila. Masalah hak asasi manusia dapat dipahami sebagai operasionalisasi Pancasila. $^{15}$

\footnotetext{
${ }^{14}$ Bagir Manan, Op. Cit, hlm. 28.

15 Syamsir Rozali Abdullah, Perkembangan HAM dan Peradilan HAM di Indonesia, Ghalia Indonesia, Jakarta, 2002, hlm. 12.
} 
Dari kelima sila yang diamanatkan dalam Pancasila dapat diuraikan hubungan antara HAM dengan Pancasila sebagai berikut: ${ }^{16}$

1. Sila pertama, Ketuhanan Yang Maha Esa. Sila ini mengamanatkan bahwa setiap warga negara bebas untuk memeluk agama dan kepercayaan masing-masing. Hal ini tentunya selaras dengan Pasal 2 Deklarasi Universal Hak Asasi Manusia (DUHAM) dimana terdapat perlindungan HAM dari adanya diskriminasi atas dasar jenis kelamin, warna kulit, agama, ras, bahasa, politik, rasial, asal-usul kebangsaan dan statusnya.

2. Sila kedua, Kemanusiaan yang Adil dan Beradab. Sila ini mengamanatkan adanya persamaan derajat, persamaan hak dan persamaan kewajiban antara sesama manusia sebagaimana tercantum dalam Pasal 7 DUHAM yang melarang adanya diskriminasi dalam bentuk apapun juga.

3. Sila ketiga, Persatuan Indonesia. Sila ini mengamanatkan adanya unsur pemersatu diantara warga negara dan semangat rela berkorban dan menempatkan kepentingan bangsa dan negara diatas kepentingan pribadi atau golongan. Hal ini sesuai dengan prinsip HAM dimana hendaknya sesama manusia bergaul satu sama lainnya dalam semangat persaudaraan. Hal ini sesuai dengan prinsip HAM dimana hendaknya sesama manusia bergaul satu sama lainnya dalam semangat persaudaraan. Sesuai dengan Pasal 1 DUHAM yang menentukan bahwa semua orang dilahirkan merdeka dan mempunyai martabat dan hak-hak yang sama. Mereka dikaruniai akal dan hati nurani dan hendaknya bergaul satu sama lain dalam persaudaraan.

4. Sila keempat, Kerakyatan Yang Dipimpin Oleh Hikmat Kebijksanaan Dalam Permusyawaratan Perwakilan. Inti dari sila ini adalah musyawarah dan mufakat dalam setiap penyelesaian masalah dan pengambilan keputusan sehingga setiap orang tidak dibenarkan untuk mengambil tindakan sendiri atas inisiatif sendiri yang

16 http://www.pusakaindonesia.org/pancasilamemayungi-hak-asasi-manusia-ham/ dapat mengganggu kebebasan orang lain. Hal ini sesuai pula dengan Deklarasi HAM PBB.

5. Sila kelima, Keadilan Sosial Bagi Seluruh Rakyat Indonesia. Asas keadilan dalam HAM tercermin dalam sila ini, dimana keadilan disini ditujukan bagi kepentingan umum tidak ada pembedaan atau diskriminasi antar individu.

Dalam sejarah perjalanan bangsa Indonesia yang telah melewati kurun waktu berlakunya tiga konstitusi, yakni UUD 1945, Konstitusi RIS 1949 dan UUDS 1950 kesemuanya memuat ketentuan-ketentuan HAM dalam bidang politik, sipil, ekonomi, sosial dan budaya. ${ }^{17}$ Dengan adanya pengakuan akan HAM di Indonesia dalam UUD 1945 yang mendahului lahirnya DUHAM 10 Desember 1948 maka seharusnya bangsa Indonesia lebih maju dari bangsa lain dalam memberikan jaminan perlindungan akan HAM.

Oleh karena persoalan HAM tidak lagi bersifat nasional tetapi internasional, maka hubungan antara hukum nasional harus sejalan dengan kewajiban hukum internasional, hal mana pengaturan hukum nasional tidak boleh bertentangan dengan apa yang dibebankan oleh kewajiban hukum internasional. ${ }^{18}$ Mengenai hubungan antara kedua perangkat hukum ini terdapat dua teori yaitu teori monisme dan dualisme.

Berdasarkan pandangan monisme dengan para pelopornya antara lain Hans Kelsen dan Georges Scelle, menyatakan semua hukum (hukum internasional dan hukum nasional) merupakan satu sistem kesatuan hukum yang mengikat baik terhadap individu-individu dalam suatu negara ataupun terhadap negara-negara dalam masyarakat internasional. Dalam teori monisme terdapat pula dua pandangan, yaitu yang memberikan primat pada hukum nasional atas hukum internasional dan primat hukum internasional atas hukum nasional. ${ }^{19}$ Inti ajaran

${ }^{17}$ Bagir Manan, Op. Cit, hlm. 80.

18 Titon Slamet Kurnia, Reparasi Terhadap Korban Pelanggaran HAM di Indonesia, Citra Aditya Bakti, Bandung, 2005, hlm. 241.

19 Boer Mauna, Hukum Internasional: Pengertian Peranan dan Fungsi Dalam Era 
monisme primat hukum nasional bahwa keterkaitan antara hukum nasional dan hukum internasional, maka penerapan utamanya terletak pada hukum nasional, karenanya secara hirarki kedudukan hukum nasional lebih tinggi dari pada hukum internasional. ${ }^{20}$ Sedangkan ajaran dualisme dengan beberapa pelopornya seperti Triepel dan Anzilotti menyatakan hal sebaliknya, bahwa hukum internasional dan hukum nasional adalah dua sistem hukum yang terpisah, berbeda satu sama lain. ${ }^{21}$

Dalam kaitannya dengan eksistensi ketentuan Pasal 43 UU No. 26 Tahun 2000 yang secara implisit menganut hukum secara surut, dapatlah dikemukakan bahwa penerapan ketentuan ini secara teoritis sejalan dengan teori monisme primat hukum nasional. Sebab pembentukan Pengadilan HAM Ad Hoc yang menerapkan hukum berdaya surut sesungguhnya berpijak pada ketentuan hukum nasional yakni UU No. 26 Tahun 2000 dan UU No. 39 Tahun 1999. Jadi tidak didasarkan atas primaritas hukum internasional seperti Resolusi DK PBB.

\section{Ketentuan yang Menyimpangi Asas Non- Retroaktif dalam Hukum Internasional}

Sebagaimana dikemukakan sebelumnya, berbagai ketentuan hukum internasional secara eksplisit telah menegaskan tentang diakuinya larangan memberlakukan surut atas suatu

Dinamika Global, Edisi ke-2, Alumni, Bandung, 2005, hlm. 12-13.

20 Mochtar Kusumaatmadja, Pengantar Hukum Internasional, Bandung, Binacipta, 1976, hlm.43.

${ }^{21}$ Perbedaan dalam teori dualisme ini terletak pada: (1) Sumber Hukum: hukum nasional bersumber pada hukum kebiasaan dan hukum tertulis suatu negara, sedangkan hukum internasional berdasarkan pada hukum kebiasaan dan hukum yang lahir atas kehendak bersama negara-negara; 2) Perbedaan Mengenai Subjek: subjek hukum nasional adalah individu-individu yang terdapat dalam suatu negara ataupun terhadap negara-negara dalam masyarakat internasional; 3) Perbedaan Mengenai Kekuatan Hukum: hukum nasional mempunyai kekuatan yang mengikat dibandingkan dengan hukum internasional yang lebih bersifat mengatur negara-negara. Lihat dalam Mochtar Kusumaatmadja, ibid. ketentuan pidana. Namun demikian dalam hukum internasional khususnya berkaitan dengan penegakkan hak-hak asasi manusia, diatur pula tentang kemungkinan untuk menerapkan hukum secara surut. Pengaturan yang memungkinkan disimpanginya asas nonretroaktif tertuang dalam beberapa instrumen internasional baik yang sifatnya berupa deklarasi maupun kovenan. Tentang ketentuan tersebut diantaranya dapat dijumpai dalam Pasal 103 Charter of the United Nations, yang berbunyi:

"In the event of a conflict between the obligations of the Members of the United Nations under the present Charter and their obligations under any other

international agreement, their obligations under the present Charter shall prevail".

Ketentuan ini menjelaskan, apabila terdapat pertentangan antara kewajibankewajiban anggota PBB menurut piagam ini serta kewajiban-kewajiban para anggota berdasarkan persetujuan internasional lainnya, maka yang berlaku ialah kewajiban-kewajiban menurut piagam ini. Hal ini berarti bahwa asas lex posteriori derogat legi priori (peraturan yang terbaru mengesampingkan peraturan yang lama) dapat dikecualikan oleh Pasal 103 Charter of the United Nations. ${ }^{22}$ Menurut I Wayan Parthiana, pasal ini tidak menyatakan secara eksplisit adanya pembedaan antara kewajiban negara-negara sebagai anggota PBB yang bersumber pada perjanjian-perjanjian yang telah berlaku sebelum berlakunya Piagam dan yang bersumber pada perjanjian-perjanjian yang berlaku sesudahnya. Tidak adanya penegasan tersebut, maka piagam harus diutamakan penerapannya apabila bertentangan baik dengan kewajiban yang bersumber pada perjanjian yang berlaku sebelum atau sesudahnya. Bahkan berlaku surutnya piagam tersebut tidak secara tegas dinyatakan hingga kapan diberlakukan, sepanjang kewajiban yang bersumber dari perjanjian itu bertentangan dengan ketentuan

${ }^{22}$ Agustinus Supriyanto, Urgensi Memahami Beberapa Aspek Hukum Internasional Dalam Mengamandemen Pasal-Pasal Tertentu UUD 1945, Jurnal Mimbar Hukum, Volume X, No. 36, 2000, hlm. 23-24. 
piagam, maka ketentuan piagam inilah yang mesti diutamakan. ${ }^{23}$

Pengecualian terhadap asas nonretroaktif, tersimpul pula di dalam Pasal 29 Ayat (2) Universal Declaration of Human Rights (UDHR) 1948 yang menyatakan:

"In the exercise of his rights and freedoms, everyone shall be subject only tosuch limitations as are determinied by law solely for the purpose of securing due recognition and respect for the rights and freedoms of others and of meeting the just requirements of morality, public order,

and the general welfare in a democratic society".

Inti dari ketentuan ini, bahwa di dalam menjalankan hak-hak dan kebebasankebebasannya setiap orang tunduk kepada pembatasan-pembatasan yang ditetapkan oleh undang-undang guna menjamin pengakuan serta penghormatan hak-hak dan kebebasan orang lain, serta untuk memenuhi syarat-syarat yang adil dalam hal kesusilaan, ketertiban dan kesejahteraan umum dalam suatu masyarakat yang demokratis. Berdasarkan aturan ini maka dapat dipahami kemudian, apabila asas nonretroaktif yang sebelumnya dianut dalam ketentuan Pasal 11 Ayat (2) UDHR menjadi terbuka untuk dikecualikan.

Ketentuan selanjutnya yang memberikan kemungkinan untuk menerapkan hukum secara surut terkandung di dalam Pasal 15 Ayat (2) ICCPR 1966. Kendati di dalam ketentuan yang sama yaitu, Pasal 15 Ayat (1) ICCPR dinyatakan adanya pengakuan terhadap asas non-retroktif. Akan tetapi ketentuan Ayat (1) tersebut menjadi relatif keberlakuannya manakala mengacu pada ketentuan Pasal 15 Ayat (2) yang secara implisit merupakan pengecualian terhadap Pasal 15 Ayat (1). Jelasnya, Pasal 15 Ayat (2) ICCPR berbunyi sebagai berikut:

"Nothing in this article shall prejudice the trial and punishment of any person for any act or omission which, at the time when it was committed, was criminal according to 112. the general principles of law recognized by the community of nations".

Dapat dikatakan bahwa ketentuan tersebut merupakan ketentuan yang menentang praktik impunitas. Ketentuan tersebut menegaskan tidak akan menghambat ataupun menghalang-halangi pemidanaan terhadap seseorang atas perbuatannya yang dianggap merupakan kejahatan berdasarkan prinsip-prinsip hukum umum yang diakui oleh masyarakat bangsabangsa. Berlandaskan ketentuan ini, maka asas non-retroaktif seperti yang dimaksudkan dalam Pasal 15 Ayat (1) dimungkinkan untuk dikesampingkan. Sebab asas non-retroaktif tidak dapat diterapkan terhadap pelaku tindak kejahatan, yang mana kejahatan atau perbuatan tersebut dapat digolongkan sebagai kejahatan berdasarkan prinsip-prinsip hukum umum yang diakui masyarakat bangsa-bangsa (community of nations). ${ }^{24}$ Kendatipun perbuatan tersebut belum diatur dalam perundang-undangan sebagai suatu kejahatan, namun atas dasar prinsip hukum internasional yang mengakui kejahatan tersebut bertentangan dengan hukum internasional (crime under international law, crime jure gentium) yang merupakan musuh umat manusia (hostis humani generis), maka terhadap para pelaku kejahatan dapat dilakukan peradilan untuk dimintakan pertanggungjawabannya. ${ }^{25}$

Kemungkinan lain penerapan surut suatu hukum internasional yaitu berkenaan dengan munculnya kaidah hukum yang sifatnya jus cogens. Adapun penjelasan mengenai jus cogens ini menurut Pasal 53 Konvensi Wina 1969 dan Konvensi Wina 1986 menentukan bahwa jus cogens atau peremptory norm of general international law adalah norma yang sifatnya kuat dan imperatif yang diakui oleh masyarakat internasional secara keseluruhan sebagai kaidah hukum yang tidak dapat diganti, kecuali apabila norma hukum internasional yang baru mempunyai sifat yang sama. ${ }^{26}$

Dalam kaitannya dengan kemungkinan berlaku surutnya suatu kaidah hukum yang tergolong jus cogens sebagaimana yang disebutkan di atas, Pasal 64 kedua konvensi

\footnotetext{
${ }^{24}$ Ibid, hlm. 110 dan 113.

${ }^{25} \mathrm{Ibid}$, hlm. 110.

${ }^{26}$ Ibid, hlm. 107-108.
} 
tersebut merumuskan: "If a new peremptory norm of general international law emerges, any existing treaty which is in conflict with that norm becomes void and terminates." Pasal ini menjelaskan, bila kemudian muncul suatu norma hukum internasional baru, maka perjanjian-perjanjian yang bertentangan dengan norma baru tersebut menjadi tidak sah dan berakhir. Dengan kata lain jika suatu perjanjian internasional yang telah berlaku terlebih dahulu ternyata bertentangan dengan norma yang bersifat jus cogens, kendati norma ini munculnya paling belakangan, maka peranjian yang sudah ada sebelumnya menjadi batal. Adanya ketentuan-ketentuan semacam ini tentunya menunjukkan bahwa, jus cogens sifatnya berlaku surut karena dapat mengesampingkan asas non-retroaktif. Dengan demikian Konvensi Wina secara jelas memberikan prioritas atau primat pada jus cogens. $^{27}$

\section{Penyimpangan Terhadap Asas Non- Retroaktif dalam Perkara Pelanggaran HAM Berat di Peradilan Internasional}

Pada awalnya, praktek peradilan internasional terhadap para pelaku pelanggaran HAM berat ditempuh oleh masyarakat internasional dengan membentuk ad hoc extrajudicial tribunal. Sejak berakhirnya PD II, disepakati bahwa segala bentuk kejahatan terhadap kemanusiaan harus ditentang dan kepada para pelakunya sedapat mungkin diadili. Apabila kemudian terbukti bersalah, maka harus dihukum untuk menunjukkan bahwa jenis kejahatan ini sama sekali tidak bisa ditolerir dan harus dicegah dari kemungkinan berulang dimasa yang akan datang. Pikiran inilah yang mendasari dan menjadi alasan dari pembentukan ad hoc extra judicial tribunal. Peradilan ini bersifat extra legal atau extra judicial, karena dibentuk dengan sangat terpaksa untuk menyiasati kekosongan norma-norma internasional dan adanya pertentangan antara

27 Boer Mauna, Hukum Internasional: Pengertian Peranan dan Fungsi Dalam Era Dinamika Global, Edisi ke-2, Alumni, Bandung, 2005, hlm. 153; I Wayan Parthiana, loc. Cit. norma internasional dan norma nasional. Dalam konteks ini peradilan yang awal mula dibentuk adalah peradilan untuk kasus Nuremberg (IMT) 1945 dan Tokyo (IMTFE) $1946 .{ }^{28}$

Kegagalan untuk mengadili pelaku kejahatan terhadap kemanusiaan pada akhir PD I tampaknya turut mengilhami untuk menuntut para pelaku kejahatan dengan model mahkamah kejahatan internasional yang berbeda. Piagam London yang disepakati tanggal 8 Agustus 1945 menjadi dasar bagi pembentukan Mahkamah Nuremberg sebagai forum untuk mengadili para penjahat perang Jerman. ${ }^{29}$

Mahkamah Nuremberg menerapkan prinsip ex post facto yang bertentangan dengan maxim nullum crimen sine lege, nulla poena sine lege atau nullum delictum nulla poena sine praevia lege poenali. Dengan model yang kurang lebih sama dengan Mahkamah Nuremberg, pada kawasan Timur Jauh dibentuk Mahkamah Tokyo yang menerapkan pula hukum berdaya surut dalam mengadili para pelaku kejahatan perang Jepang. ${ }^{30}$

Mahkamah Nuremberg dan Tokyo telah menciptakan konsep-konsep hukum internasional baru yang penting serta diakui oleh PBB dan diadopsi oleh hukum internasional dan dilaksanakan oleh pengadilan pidana internasional lainnya. Selain berlakunya hukum secara retroaktif, juga terdapat asas pertanggungan jawab pribadi yang merupakan prinsip baru yang diatur dalam Statuta IMT Nuremberg dan IMTFE Tokyo. ${ }^{31}$ Bahkan prinsip-prinsip peradilan Nuremberg sudah

${ }^{28}$ Zainal Abidin, Pengadilan Hak Asasi Manusia di Indonesia: Regulasi, Penerapan dan Perkembangannya, Makalah yang disampaikan pada Kursus HAM untuk Pengacara ke XIV, diselenggarakan oleh ELSAM, Jakarta, 2010, http://www.elsam.or.id/downloads/

1290394945_Paper_Pengadilan_HAM_untuk_Kursu s_HAM.pdf, hlm. 6.

29 Arie Siswanto, Yurisdiksi Material Mahkamah Kejahatan Internasional, Ghalia Indonesia, Bogor, 2005, hlm, 3.

${ }^{30}$ Ibid, hlm. 4.

${ }^{31}$ Eddy Djunaedi, dari Pengadilan Militer Internasional Nuremberg ke Pengadilan Hak Asasi Manusia, Tatanusa, Jakarta, 2003, hlm. 16-18. 
diakui sebagai hukum kebiasaan internasional. Praktik hukum internasional tersebut terus dilanjutkan dan terbukti dengan pembentukan ICTY dan ICTR. ${ }^{32}$ Menurut Yudha Bhakti, dengan adanya penerimaan terhadap prinsipprinsip Nuremberg yang telah diadopsi PBB tersebut, maka hal itu dapat dikatakan sebagai bentuk tanggung jawab internasional. ${ }^{33}$

Berdasarkan Pasal 6 Statuta IMT, Mahkamah Nuremberg memiliki kewenangan untuk mengadili kejahatan peradamaian (crimes against peace), kejahatan perang (war crimes) dan kejahatan terhadap kemanusiaan (crimes againsy humanity). Pengaturan prinsip pertanggungjawaban pribadi tampak dalam Pasal 6 Statuta IMT yang berbunyi "war criminals of European Axis countries... whether as individuals or as members of organizations...”. Selanjutnya Statuta yang ditetapkan tahun 1945 ini berlaku surut untuk kejahatan yang terjadi sebelum dibuatnya Statuta, yaitu selama PD II dan berlangsung di mana saja "...for the trial and punishment of the major war criminals for the European Axis countries." 34

Saat berlangsungnya peradilan, para terdakwa melakukan sanggahan atas dakwaan penuntut umum, terutama menyangkut berlakunya hukum secara retroaktif ini. Menurut para terdakwa, berlakunya hukum berdaya surut yang diterapkan oleh Mahkamah Nuremberg telah bertentangan dengan asas legalitas yang berlaku dalam hukum pidana. ${ }^{35}$ Bahwa mahkamah yang pembentukannya melalui London Charter, dibuat setelah ada serangkaian perbuatan Nazi Jerman selama PD II. Mahkamah juga dianggap sebagai pengadilan politik dan lebih pada balas dendam (Lex Talionis) negara-negara sekutu terhadap negara-

${ }^{32}$ Romli Atmasamita, Op. Cit, hlm. 56.

33 Yudha Bhakti Ardhiwisastra, Hukum Internasional; Bunga Rampai, Alumni, Bandung, 2003, hlm. 175.

${ }^{34}$ Eddy Djunaedi Karnasudirdja, Op. Cit., hlm. 16; Lihat Pasal 6 Charter of the International Military Tribunal-Nuremberg (IMT).

${ }^{35}$ Ibid; Eddy O.S. Hiariej, Pengadilan atas Beberapa Kejahatan Serius terhadap HAM, Erlangga,Jakarta,2010, hlm. 59. negara poros atas penyerangan yang dilakukan selama PD II. ${ }^{36}$

Sanggahan yang dikemukakan para terdakwa ditolak oleh Majelis Hakim IMT dengan argumen, bahwa asas non-retroaktif hanya berlaku untuk kejahatan biasa (ordinary crimes) yang terjadi di wilayah hukum nasional di mana hukum pidana nasional diberlakukan. Asas non-retroaktif tidak berlaku bagi kejahatan internasional, terlebih lagi sejumlah perangkat hukum internasional antara lain yang mengatur humanitarian law, konvensi-konvensi internasional dan hukum perang (law of the war -jus beli) telah ada sebelumnya dan telah diterima oleh negara-negara di dunia. ${ }^{37}$

Beberapa pertimbangan yang dikemukakan oleh Majelis Hakim IMT berkenaan dengan disimpanginya asas nonretroaktif yang dianut oleh mahkamah, diantaranya: ${ }^{38}$

1. Hakim Henri Donnedieu de Vabres menyatakan, menghukum dengan melanggar asas legalitas memang tidak adil, akan tetapi jauh lebih tidak adil lagi apabila tidak menghukum orang yang bersalah karena kejahatan yang dilakukannya.

2. Jika ada inkonsistensi antara undang-undang (hukum Positif) dan keadilan maka yang lebih diutamakan adalah keadilan.

3. 'Strong' Radbruch argument of the superior and compelling needs of justice. Bahwa, meskipun perbuatan terdakwa adalah legal, namun perbuatan tersebut tercela sehingga keadilan membenarkan untuk menghukum perbuatan tersebut sekarang. Sebab itu, penghukuman yang diberikan saat ini adalah contoh dimana penghukuman secara retroaktif dibenarkan atas dasar prinsipprinsip keadilan yang lebih tinggi derajatnya mengalahkan prinsip non-retroaktif.

Selanjutnya, berdasarkan preseden pembentukan Mahkamah Nuremberg, PBB membentuk Komisi Hukum Internasional (International Law Commission (ILC) melalui Resolusi Majelis Umum PBB No.174 (II) yang

\footnotetext{
${ }^{36}$ Ibid.

37 Eddy Djunaedi Karnasudirdja, Op. Cit., hlm.16-17.

${ }^{38}$ Lihat dalam, Eddy O.S. Hiariej, Op. Cit., hlm. 60-61.
} 
ditetapkan pada tanggal 21 November 1947. Komisi ini diberi mandat untuk menyusun sebuah standar hukum internasional sebagai pedoman bagi setiap negara anggota PBB untuk memformulasikan prinsip-prinsip hukum yang muncul dalam Mahkamah Nuremberg. ${ }^{39}$ Pada Tanggal 29 Juli 1950, ILC menetapkan prinsipprinsip hukum tersebut, yang dikenal dengan tujuh prinsip umum hukum internasional (the Nuremberg Principles). ${ }^{40}$

Formulasi prinsip Nuremberg memiliki arti penting terhadap pembentukan mahkamah kejahatan internasional selanjutnya, terbukti dengan diakui dan diadopsinya prinsip-prinsip tersebut pada IMTFE Tokyo 1946. Sesuai Pasal 5 Statuta IMTFE Tokyo disebutkan bahwa Mahkamah Tokyo memiliki yurisdiksi untuk mengadili kejahatan terhadap perdamaian (crimes against peace), kejahatan perang konvensional (conventional war crimes) dan kejahatan terhadap kemanusiaan (crimes against humanty). ${ }^{41}$ Seperti diutarakan di atas, peradilan IMT Nuremberg dan IMTFE Tokyo memberikan dampak yang penting dalam sejarah hukum internasional dan juga terhadap pengadilan pidana internasional, oleh karena sebelumnya bagi kejahatan internasional diadili oleh masing-masing negara dimana kejahatan dilakukan sesuai hukum nasional masingmasing. ${ }^{42}$

Kemudian pada masa-masa sesudahnya, pembentukan ICTY sebagai Mahkamah Pidana Internasional Ad Hoc yang menerapkan hukum secara surut kembali diberlakukan untuk mengadili pelaku pelanggaran HAM berat di negara-negara bekas Yugoslavia, melalui Resolusi Nomor 827/1993 DK PBB. Dasar pembentukan ini yang membedakan dengan Mahkamah Nuremberg dan Tokyo, di mana

39 Agung Yudhawiranata, Analisa Kritis Terhadap Pengadilan HAM Internasional, melalui, http://pusham.uii.ac.id/upl/article/id Berkaca\%20Pa da\%20Tokyo \%20dan\%20Nuremberg.pdf, hlm. 1 hlm.16-19

40 Eddy Djunaedi Karnasudirdja, Op. Cit.,

${ }^{41}$ Lihat Pasal 5 Charter of the International Military Tribunal for The Far East-Tokyo (IMTFE) hlm. 21. pihak yang menentukan dalam upaya pembentukan ICTY ini adalah Dewan Keamanan PBB. ${ }^{43}$ Pembentukan mahkamah didasari pula oleh kenyataan, bahwa Yugoslavia tidak dapat dipercaya untuk melaksanakan peradilan, selain memang dalam beberapa kasus justru dipimpin oleh para kriminal. ${ }^{44}$

Adapun yurisdiksi ratione materiae meliputi, pelanggaran berat terhadap Konvensi Jenewa 1949, pelanggaran terhadap kebiasaan perang, genosida dan kejahatan terhadap kemanusiaan (vide Pasal 2-Pasal 5 Statuta ICTY). Menyangkut yurisdiksi tempat dan waktu (territorial and temporal jurisdiction) berdasarkan Pasal 8 Statuta disebutkan, peradilan ICTY diberlakukan sejak tanggal 1 Januari 1991 diwilayah bekas negara Yugoslavia. Termasuk di dalam yurisdiksi ICTY ialah para pelaku kejahatan di Bosnia dan Kosovo. ${ }^{45}$ Dengan demikian mengacu pada tanggal pembentukkan tribunal dan yurisdiksi waktunya, maka tampaklah bahwa prinsip untuk tidak dituntut atas dasar hukum yang berlaku surut tidak dianut oleh ICTY.

Dalam persidangan sejumlah terdakwa mengajukan keberatannya atas peradilan ICTY yang dinilai menyimpangi asas non-retroaktif. Hal ini sebagaimana nampak dalam perkara Dusco Tadic yang dengan tegas menolak peradilan ICTY karena bertentangan dengan asas legalitas. Tadic mempertanyakan keabsahan pembentukan forum ICTY oleh DK PBB yang dianggapnya tidak sah, sebab menurutnya PBB bukanlah lembaga yang berwenang menetapkan hukum dan bukan badan legislatif. $^{46}$

Majelis Hakim ICTY tidak menerima sanggahan Tadic dengan beberapa pertimbangan yang antara lain menyatakan, merujuk pada Mahkamah Nuremberg yang menyimpulkan bahwa tanggung jawab pidana internasional tidak dapat dihalangi karena tidak adanya pasal-

${ }^{43}$ Arie Siswanto, Op. Cit., hlm. 6.

44 Andrey Sujatmoko, Tanggung Jawab Negara atas Pelanggaran Berat HAM, Grasindo, Jakarta, 2005, hlm. 153. hlm. 29.

45 Eddy Djunaedi Karnasudirdja, Op. Cit., ${ }^{46}$ Lihat, Eddy O.S. Hiariej, Op. Cit, hlm. 152153. 
pasal dalam perjanjian tersebut untuk menghukum pelaku. Bahwa kejahatan atas hukum internasional hanya bisa ditegakkan dengan menghukum pelaku kejahatan tersebut. Antonio Casese, sebagai presiden pada Appeals Chamber ICTY berpendapat, bahwa pembentukan organ pengadilan oleh DK PBB telah sesuai dengan aturan hukum internasional. Disamping itu, asas legalitas dalam hukum pidana internasional lebih menekankan pada aspek keadilan. Bahkan sejumlah fakta dalam persidangan juga menunjukkan bahwa Tadic terlibat langsung atas pelanggaran berat terhadap Konvensi Jenewa 1949 dan kejahatan terhadap hukum kebiasaan perang. ${ }^{47}$

Selanjutnya pada tahun 1994 dibentuk pula Mahkamah Pidana Internasional untuk mengadili pelaku kejahatan perang dan genosida di Rwanda (ICTR) juga oleh DK PBB. Dalam kasus Rwanda 1994 DK PBB memutuskan pembentukan Mahkamah Pidana Internasional pada tanggal 8 November 1994, tanpa menunggu hasil konklusi akhir dari Komisi Ahli. Hal ini didasari karena keberadaan mahkamah saat itu adalah mendesak, sebab tindakan aksi balas dendam mulai dilancarkan. ${ }^{48}$

Yurisdiksi temporis-nya ICTR yaitu untuk mengadili para pelaku kejahatan di wilayah Rwanda dan negara-negara tetangga yang terjadi pada kurun waktu antara tanggal 1 Januari 1994 hingga tanggal 31 Desember 1994. ${ }^{49}$ Maka, dilihat dari segi waktu pembentukan dan terjadinya kejahatan, ICTR juga memberlakukan hukum berdaya surut. Sedangkan kejahatankejahatan sebagai pelanggaran HAM berat yang menjadi kewenangan mahkamah meliputi, kejahatan genosida, kejahatan terhadap kemanusiaan, serta pelanggaran atas Pasal 3 Konvensi Genewa dan Protokol Tambahan II. ${ }^{50}$

Beberapa pertimbangan Majelis Hakim ICTR sehubungan dengan berlakunya hukum secara retroaktif, diantaranya: berdasarkan teori

\footnotetext{
${ }^{47}$ Ibid, hlm. 153-158.

${ }^{48}$ Arie Siswanto, Op. Cit, hlm. 8.

${ }^{49}$ Lihat Pasal 1 jo Pasal 7 Ayat (1) Statute of the International Criminal Tribunal for Rwanda.

50 Lihat Pasal 2-Pasal 4 Statute of the International Criminal Tribunal for Rwanda.
}

pemidanaan relatif yaitu pidana bertujuan preventif, tidak adanya ancaman pidana yang jelas dalam Statuta ICTR, serta pemberlakuan surut statuta memang bertentangan dengan asas legalitas. Namun guna melindungi masyarakat dalam pengertian keadilan terhadap para korban, pengabaian terhadap asas legalitas dapat dibenarkan. Terlebih, menyangkut jenis-jenis kejahatan yang dikategorikan sebagai pelanggaran HAM berat. Kemudian Statuta ICTR tidak secara eksplisit menyatakan bahwa pelanggaran terhadap kejahatan-kejahatan yang ada dalam statuta diancam dengan pidana, hal ini bertentangan dengan makna kedua dari asas legalitas, yaitu nullum crimen, noela poena sine lege scripta (tidak dapat dipidana hanya berdasarkan hukum kebiasaan dan tidak ada pidana lain kecuali yang ditentukan undangundang). Terkait ini, kiranya Majelis Hakim ICTR, berpedoman pada hukum kebiasaan internasional sebagaimana terbentuknya Mahkamah Nuremberg, Tokyo dan ICTY. ${ }^{51}$

\section{Ketentuan yang Menyimpangi Asas Non- Retroaktif dalam Hukum Nasional Indonesia}

Dalam instrumen hukum nasional Indonesia, justifikasi normatif terhadap pemberlakuan hukum secara surut dalam perkara pelanggaran HAM berat didasarkan pada Penjelasan atas Pasal 4 UU No. 39 Tahun 1999 yang menyatakan, "Hak untuk tidak dituntut atas dasar hukum yang berlaku surut dapat dikecualikan dalam hal pelanggaran berat terhadap hak asasi manusia yang digolongkan kedalam kejahatan terhadap kemanusiaan." Pasal penjelasan ini merupakan pengecualian terhadap keberadaan asas nonretroaktif yang sebelumnya dicantumkan dalam pasal yang dijelaskannya. ${ }^{52}$ Akan tetapi sifat

${ }^{51}$ Lihat catatan kritis Eddy O.S. Hiariej, Op. Cit, hlm. 199-204.

${ }^{52}$ Pasal 4 UU No. 39 Tahun 1999: "Hak untuk hidup, hak untuk tidak disiksa, hak kebebasan pribadi, pikiran dan hati nurani, hak beragama, hak untuk tidak diperbudak, hak untuk diakui sebagi pribadi dan persamaan dihadapan hukum, dan hak untuk tidak dituntut atas dasar hukum yang berlaku surut adalah hak asasi manusia yang tidak dapat dikurangi dalam keadaan apa pun dan oleh siapa 
mengikat pasal penjelasan ini dipertanyakan apabila dikaitkan dengan sistem perundangundangan kita, yaitu sejauh mana suatu pasal dapat dikecualikan atau dikesampingkan oleh ketentuan yang ada dalam bagian penjelasan. Menurut Parthiana penempatan substansi seperti dalam penjelasan ini sebaiknya diatur dalam ayat dari pasal tersebut atau bila perlu diatur dalam pasal tersendiri. ${ }^{53}$

Kemudian, ketentuan berikutnya yang melegitimasi dikesampingkannya asas nonretroaktif secara implisit terkandung di dalam Pasal 43 Ayat (1) UU No. 26 Tahun 2000 sebagai dasar pembentukan Pengadilan HAM Ad Hoc, yang berbunyi, "Pelanggaran hak asasi manusia yang berat yang terjadi sebelum diundangkannya Undang-undang ini, diperiksa dan diputus oleh Pengadilan HAM Ad Hoc". Lebih lanjut di dalam bagian umum penjelasan atas undang-undang a quo menyebutkan, "mengenai pelanggaran hak asasi manusia yang berat seperti genosida dan kejahatan terhadap kemanusiaan yang berdasarkan hukum internasional dapat digunakan asas retroaktif." 54 Hal ini berarti Undang-undang Pengadilan HAM bersifat retroaktif, sebab mengatur penyelesaian pelanggaran HAM berat sebelum diundangkannya undang-undang ini. Bahkan daya berlaku surut ketentuan ini tidak secara tegas memberikan batasan sejak tahun berapa kasus-kasus pelanggaran HAM berat masa lalu dapat diperiksa.

pun." Pasal lainnya dari undang-undang a quo yang menyatakan larangan berkekuatan surut, yaitu Pasal 18 Ayat (2) yang merumuskan, "Setiap orang tidak boleh dituntut untuk dihukum atau dijatuhi pidana, kecuali berdasarkan suatu peraturan perundangundangan yang sudah ada sebelum tindak pidana itu dilakukannya."

${ }^{53}$ Lihat lebih lanjut dalam I Wayan Parthiana,

Op. Cit, hlm. 116-118. Lihat juga Agus Raharjo, Problematika Asas Retroaktif Dalam Hukum Pidana Indonesia, melalui,

http://fh.unsoed.ac.id/sites/default/ files/VOL8J2008\%20AGUS\%20RAHARJO.pdf, hlm. 75 .

${ }^{54}$ Lihat bagian penjelasan umum UU No. 26 Tahun 2000, paragraf delapan.
Secara konstitusional hukum berkekuatan surut sebagaimana yang dianut di dalam UU No. 26 Tahun 2000, pada dasarnya berpijak pada Pasal 28J Ayat (2) UUD 1945 hasil amandemen kedua yang menyatakan:

"Dalam menjalankan hak dan kebebasannya, setiap orang wajib untuk tunduk kepada pembatasan yang ditetapkan dengan undang-undang dengan maksud semata-mata untuk menjamin pengakuan serta penghormatan atas hak dan kebebasan orang lain dan untuk memenuhi tuntutan yang adil sesuai dengan pertimbangan moral, nilai-nilai agama, keamanan dan ketertiban umum dalam suatu masyarakat demokratis."

Ketentuan tersebut secara implisit merupakan pembatasan terhadap asas nonretroaktif yang tersimpul dalam Pasal 28I Ayat (1) UUD 1945. Sebab meskipun hak untuk tidak dituntut atas dasar hukum yang berlaku surut termasuk hak yang bersifat non-derogable akan tetapi hak tersebut tidak bediri sendiri melainkan bersanding pula dengan hak-hak lainnya yang juga bersifat non-derogable diantaranya yaitu hak untuk hidup. ${ }^{55}$

Jadi asas non-retroaktif yang dianut di dalam Pasal 28I Ayat (1) sifatnya menjadi relatif, sebab adanya pengecualian oleh Pasal 28J Ayat (2) UUD 1945 dilakukan sebagai konsekuesi logis karena terjadinya pelanggaran terhadap hak lainnya yang juga bernilai nonderogable, yakni hak untuk hidup yang dimiliki oleh tiap individu lainnya.

Dengan demikian ketentuan Pasal 28I Ayat (1) ini memiliki relevansi dengan Pasal 28J Ayat (2) UUD 1945. Telaah terhadap kedua ketentuan ini tidak boleh dilakukan secara sepotong-sepotong, sebab makna lebih jauh dari Pasal 28J Ayat (2) UUD 1945 ini sifatnya justru

55 Terdapat tujuh jenis hak bersifat nonderogable yang diatur dalam Pasal 28I Ayat (1) UUD 1945, yaitu: hak untuk hidup, hak untuk tidak disiksa, hak kemerdekaan pikiran dan hati nurani, hak beragama, hak untuk tidak diperbudak, hak untuk diakui sebagai pribadi dihadapan hukum, dan hak untuk tidak dituntut atas dasar hukum yang berlaku surut. 
membatasi setiap tindakan dan perbuatan seseorang demi penghormatan terhadap hak orang lain. Apabila tidak ada pembatasan terhadap hal ini, tentu berpotensi terjadinya tindakan semena-mena yang dapat mengarah pada tersulutnya tindakan anarkis. Pengertian yang terkandung dengan adanya pembatasan ini bahwa, semutlak-mutlaknya sifat mengikat dari norma konstitusi sebagai hukum tertinggi, hal itu tetap menjadi bersifat relatif. Sebab menurut Pasal 28J Ayat (2) UUD 1945 justru setiap orang (tanpa kecuali) wajib menghormati hak asasi orang lain. ${ }^{56}$

Bahwa, ketentuan Pasal 28J Ayat (2) sejalan juga dengan ketentuan Pasal 28I Ayat (5) UUD 1945 yang dapat diperbandingkan sebagai berikut:

"Untuk menegakkan dan melindungi hak asasi manusia sesuai dengan prinsip negara hukum yang demokratis, maka pelaksanaan hak asasi manusia dijamin, diatur, dan dituangkan dalam peraturan perundang-undangan."

Ketentuan Pasal 28I Ayat (5) tersebut merupakan jalan keluar bagi Pasal 28J Ayat (2) untuk membatasi atau mengecualikan eksistensi Pasal 28I Ayat (1) UUD 1945. ${ }^{57}$ Ketentuan yang berisikan non-derogable rights ini justru merupakan ketentuan yang sangat kontroversial, sebab pencantuman asas non-retroaktif di dalam ketentuan ini dipandang dapat melindungi pelaku pelanggaran berat HAM dimasa lalu. ${ }^{58}$ Karenanya dapat dipahami bahwa pengesampingan terhadap asas non-retroaktif pada Pasal 28J Ayat (2) UUD 1945 dimaksudkan sebagai perlindungan terhadap hak asasi manusia juga.

\section{Penyimpangan Terhadap Asas Non- Retroaktif dalam Perkara Pelanggaran HAM Berat di Indonesia}

${ }^{56}$ Binsar Gultom, Pelanggaran HAM dalam Hukum Keadaan Darurat di Indonesia, Gramedia Pustaka Utama, Jakarta, 2010, hlm. 191-192.

57 Ibid.

${ }^{58}$ Bagir Manan, et.al., Op. Cit, hlm. 128.
Bentuk peradilan ad hoc dalam Pasal 43 UU No. 26 Tahun 2000 yang berlaku untuk locus dan tempos delicti tertentu mengacu pada bentuk pengadilan internasional ad hoc (IMT 1945, IMTFE 1946, ICTY 1991 dan ICTR 1994), yang antara lain memungkinkan berlakunya prinsip retroaktivitas. ${ }^{59}$ Pengadilan HAM sendiri dibentuk berdasarkan Pasal 104 Ayat (1) UU No.39 Tahun 1999 tentang HAM. Adapun UU No. 26 Tahun 2000 merupakan pengganti Perppu No. 1 Tahun 1999 tentang Pengadilan HAM yang diangap tidak memadai sehingga tidak disetujui oleh DPR menjadi undang-undang. Salah-satu keberatan DPR yaitu tidak dimasukannya asas retroaktif dalam Perppu No. 1 Tahun 1999. ${ }^{60}$

Di luar amanat Pasal 104 UU No. 39 Tahun 1999 yang menjadi dasar pembentukan Pengadilan HAM, faktor lain yang membuat pengadilan ini terbentuk yakni karena munculnya desakan oleh internasional (PBB) tentang kemungkinan pembentukan pengadilan internasional, sehingga kemudian pemerintah segera mengajukan rancangan legislasi baru menggantikan Perppu No. 1 Tahun 1999 tersebut. Dalam keterbatasan waktu inilah proses pembahasan UU No. 26 Tahun 2000 berjalan, di mana pada bulan November Tahun 2000 DPR mengesahkan RUU tersebut menjadi UU No. 26 Tahun 2000 tentang Pengadilan HAM. $^{61}$

Dengan telah masuknya rekomendasi dari Commission of Inquiry ke Sekretaris Jenderal dan DK PBB, maka peradilan bagi mereka yang disangka melakukan kejahatan kemanusiaan di Tim-Tim pasca jajak pendapat melalui Pengadilan HAM Ad Hoc harus berjalan dengan sungguh-sungguh, professional,

59 Muladi, Mekanisme Domestik untuk Mengadili Pelanggaran HAM Berat Melalui Sistem Pengadilan atas Dasar UU RI No. 26 Tahun 2000, Seri Bahan Bacaan Kursus HAM untuk Pengacara X, Tahun 2005, http://www.elsam.or.id/pdf/kursusham/Mekanisme_ UU_26_2000.pdf, hlm.8.

82.

${ }^{60}$ Eddy Djunaedi Karnasudirdja, Op. Cit, hlm.

${ }^{61}$ Lihat, Zainal Abidin, Op Cit, hlm. 1-2. 
independen dan konsisten sesuai dengan standar peradilan internasional. ${ }^{62}$

Berdasarkan Keppres RI No. 53 Tahun 2001 yang ditetapkan tanggal 23 April 2001 telah dibentuk Pengadilan HAM Ad Hoc pada Pengadilan Negeri Jakarta Pusat yang bertugas untuk mengadili: "...pelanggaran HAM berat yang terjadi di Timor Timur pasca jajak pendapat dan di Tanjung Priok pada tahun 1984.” Dengan Keppres RI No. 96 Tahun 2001 yang ditetapkan tanggal 1 Agustus 2001, maka Keppres RI No. 53 Tahun 2001 telah dirubah tempus dan locus delicti sehingga kewenangan Pengadilan HAM Ad Hoc lebih dibatasi, yaitu hanya untuk mengadili: "...pelanggaran yang terjadi di Timor Timur dalam wilayah Liquica, Dili dan Soae pada bulan April 1999 dan September 1999, dan yang terjadi di Tanjung Priok pada bulan September 1984."63

Saat persidangan, para terdakwa yang diadili selain menolak keabsahan Pengadilan HAM Ad Hoc karena dianggap menerapkan hukum secara retroktif juga menyanggah tuduhan keterlibatan dalam perkara kejahatan terhadap kemanusiaan di Tim-Tim pasca jajak pendapat. Salah satunya yaitu terdakwa Eurico Barros Guterres (Nomor Perkara 04/Pid.HAM/Ad.Hoc/2002/PH.JKT.PST) yang di dalam pembelaannya antara lain menyatakan: ${ }^{64}$

1. Bahwa ketentuan Pasal 43 UU RI No. 26 Tahun 2000 tentang Pengadilan HAM, secara implisit mengandung asas retroaktif. Dengan demikian bertentangan dengan asas legalitas sebagai asas yang fundamental dalam hukum pidana yang tidak memperkenankan hukum pidana berlaku surut.

\footnotetext{
${ }^{62}$ Eddy Djunaedi Karnasudirdja, Op. Cit, hlm. 83.

${ }^{63} \mathrm{Ibid}, \mathrm{hlm} .90$.

${ }^{64}$ Disadur dari Eddy O.S. Hiariej, Op. Cit., hlm. 104-105. Lebih lengkap mengenai eksepsi Eurico Guterres dalam perkara pelanggaran HAM berat Tim-Tim dapat dilihat melalui, http://www.elsam.or.id/pdf/monham/timtim/Eurico \%20Gutterres-Eksepsi\%204\%20Juli\% 202002. PDF
}

2. Bahwa hukum pidana yang berlaku surut atas suatu ketentuan pidana hanya berlaku dalam pengadilan internasional dan tidak dalam pengadilan nasional.

Majelis Hakim Pengadilan HAM Ad Hoc yang mengadili perkara Eurico Guterres, banyak menjelaskan atau menggunakan dasar hukum baik hukum nasional maupun yurisprudensi dalam praktek-praktek peradilan internasional yang mengadili pelanggaran HAM berat. Majelis hakim secara tegas mengacu pada praktek pengadilan Nuremberg dan Tokyo, ICTY dan ICTR dalam hal mengenai tanggung jawab individu dan elemen lainnya yaitu mengenai tanggung jawab atasan yang juga menggunakan ketentuan-ketentuan internasional. Pertimbangan-pertimbangan dalam pembahasan tiap elemen yang didakwakan selalu dijelaskan dengan praktekpraktek pengadilan HAM internasional, doktrin hukum yang berkembang, prinsip-prinsip dan ketentuan-ketentuan hukum internasional. Hakim menyatakan adanya relevansi prinsipprinsip hukum internasional dalam kasus pelanggaran HAM berat di Tim-Tim. ${ }^{65}$

Beberapa pertimbangan hukum yang dikemukakan oleh majelis hakim dalam perkara Eurico Guterres tersebut, diantaranya adalah sebagai berikut: ${ }^{66}$

1. Bahwa tidak ada seorang pun berada di atas hukum, bahwa tanggung jawab dipastikan pelaksanaannya dan tidak ada pihak yang bisa lolos dari hukum karena kejahatan di masa lalu atau masa depan.

2. Bahwa kejahatan terhadap kemanusiaan, kejahatan perang dan genosida merupakan hostis humanis generis yaitu musuh bersama umat manusia, yang termasuk dalam kejahatan internasional sehingga tidak boleh lolos dari penuntutan dan penghukuman.

65 Lihat, ELSAM, Progres Report IX, Pemantauan Pengadilan HAM Ad Hoc Perkara Pelanggaran HAM Berat di Timor-Timur: Kejahatan Terhadap Kemanusiaan Tanpa Penanggung Jawab, Jakarta, 20 Desember2002,melalui,http://www.elsam.or.id/dow nloads/1268376446 Progress Report Pengadilan T imor_Timur 9.pdf, hlm. 4-5.

${ }^{66}$ Eddy O.S. Hiariej, Op. Cit, hlm. 105-108. 
3. Bahwa kejahatan terhadap kemanusiaan, sudah menjadi bagian dari prinsip hukum umum yang diakui oleh masyarakat bangsabangsa dan orang yang melakukan kekerasan (comission) atau pembiaran (omission) dapat dituntut secara retroaktif.

4. Bahwa diundangkannya UU No. 26 Tahun 2000 tentang Pengadilan HAM adalah sesuai dengan ketentuan-ketentuan hukum internasional dan kebiasaan internasional dalam mengadili pelaku pelanggaran HAM berat (vide penjelasan UU RI No. 26 Tahun 2000, serta penjelasan Pasal 7 undangundang a quo), sehingga dapat diterapkan di Indonesia, dalam hal ini sepanjang ada relevansinya dengan kasus pelanggaran HAM berat di Tim-Tim.

Kejahatan yang didakwakan terhadap Guterres, adalah kejahatan terhadap kemanusiaan berupa pembunuhan dan penganiayaan yang dalam konteks hukum nasional Indonesia merupakan pelanggaran HAM berat yang penuntutannya dapat berlaku surut sesuai Pasal 43 Ayat (1) UU No. 26 Tahun 2000. Apabila dihubungkan dengan ketentuan internasional, maka pemberlakuan surut ketentuan pidana pada kejahatan terhadap HAM seperti yang terjadi di Tim-Tim dapat dibenarkan, sebab penerapannya lebih mengutamakan nilai keadilan dibandingkan kepastian hukum dengan pertimbangan bahwa kejahatan-kejahatan tersebut merupakan pelanggaran terhadap jus cogens. ${ }^{67}$

Tidak beberapa lama setelah digelarnya Pengadilan HAM Ad Hoc untuk kasus pelanggaran HAM berat di Tim-Tim (2002), menyusul kemudian dibentuk pula peradilan yang sama guna menyelesaikan kasus pelanggaran HAM berat di Tanjung Priok (2003).

Tidak berbeda dengan persidangan atas perkara pelanggaran HAM berat di Tim-Tim, para terdakwa dalam perkara pelanggaran HAM berat di Tanjung Priok juga mengajukan penolakkannya terhadap keberadaan Pengadilan HAM Ad Hoc yang menerapkan hukum secara surut. Penolakkan atas berlakunya hukum retroaktif tersebut diantaranya sebagaimana

\footnotetext{
${ }^{67}$ Ibid, hlm.110
}

yang disampaikan oleh terdakwa R.A. ButarButar (No.Reg.Perkara 02/HAM/TJPriok/09/20003), Pranowo (No.Reg. Perkara 03/HAM/TJ-Priok/09/2003) dan Sutrisno Mascung dkk (No. Reg. Perkara 01/HAM/TJPriok/08/2003). Pada prinsipnya para terdakwa menyatakan keberatan terhadap pembentukan Pengadilan HAM Ad Hoc yang menerapkan persidangan atas dasar ketentuan pidana yang diberlakukan secara surut, sebab berlakunya hukum secara retroaktif dinilai bertentangan dengan hukum dan keadilan. Secara garis besar para terdakwa menyatakan bahwa ketentuan Pasal 4 jo Pasal 43 UU No. 26 Tahun 2000 yang dijadikan dasar dalam mengadili para terdakwa, adalah bertolak belakang dengan Pasal 28I UUD 1945 amandemen kedua. Para terdakwa juga menyatakan bahwa Pengadilan HAM Ad Hoc yang menerapkan hukum berkekuatan surut adalah tidak sejalan dengan asas legalitas sebagai asas primaritas dalam hukum pidana, seperti yang ditentukan dalam Pasal 1 Ayat (1) dan Ayat (2) KUHP. Disampaikan pula oleh para terdakwa, bahwa penerapan ketentuan pidana secara surut tidak sesuai pula dengan asas universalitas yang diakui oleh masyarakat internasional sebagaimana dinyatakan dalam Pasal 11 Ayat (2) UDHR. ${ }^{68}$ Majelis Hakim Pengadilan HAM Ad Hoc menolak permohonan yang diajukan para terdakwa tersebut di atas. Beberapa pertimbangan dari majelis hakim, antara lain: ${ }^{69}$

1. Nilai keadilan tidak diperoleh dari tingginya nilai kepastian hukum, melainkan dari keseimbangan perlindungan hukum atas korban dan pelaku kejahatan. Semakin serius bentuk kejahatan, maka semakin besar nilai

68

http://www.tempo.co/read/news/2003/10/08/055205 60/Pembela-Peristiwa-Priok-Bukan-Tanggung-

Jawab-Dandim, 8 Oktober 2003; ELSAM, Preliminary Conclusive Report Pengadilan HAM Kasus Tanjung Priok, http://www.elsam.or.id/downloads/ 1316576901_04. Preliminary_Conclusive Report12 3.pdf, hlm 23-31

${ }^{69}$ Ibid. 
keadilan yang dipertahankan, yang lebih besar dari nilai kepastian hukum.

2. Bahwa penerapan hukum secara surut tersebut tidak bertentangan dengan UUD 1945, hukum dan keadilan. Hal ini dapat dilihat dalam penjelasan umum UU No. 26 Tahun 2000, Pasal 28J Ayat (2) UUD 1945, Pasal 15 Ayat (2) ICCPR serta praktik peradilan internasional.

3. Pendapat terdakwa yang mempersoalkan penerapan hukum secara surut bertentangan dengan asas nullum crimen sine lege dalam hukum pidana dan bertentangan dengan asas universalitas, menurut majelis pendapat tersebut tidaklah tepat, sebab khusus mengenai kejahatan terhadap kemanusiaan yang banyak berkaitan dengan pelanggaran HAM berat dipandang tidak melanggar asas standar legalitas dalam pidana internasional, asas legalitas dapat disimpangi menyangkut pelanggaran HAM berat sebagai extra ordinary crime.

4. Bahwa tujuan tertib hukum tidaklah sematamata untuk mewujudkan kepastian hukum, melainkan untuk menegakkan atau menciptakan keadilan bagi semuanya accept justice for all yang mengacu pada prinsipprinsip universal HAM yang berlaku. Bahwa dalam penegakan keadilan tidak didasarkan pada adagium nullum delictum nula poena sine lege, melainkan didasarkan pada nullum delictum nula poena sine iure. Dengan prinsip ini terkandung maksud untuk menghapus atau mengakhiri praktik impunitas, yaitu sikap mengabaikan tanpa memberi hukuman terhadap pelaku pelanggaran HAM berat.

Dapat dikemukakan di sini terkait dengan diterapkannya hukum secara retroaktif dalam persidangan perkara pelanggaran HAM berat Tanjung Priok, kiranya putusan yang ditetapkan oleh pengadilan yang menolak keberatan para terdakwa adalah sudah tepat. Putusan pengadilan telah sejalan dengan praktik peradilan internasional yakni ICTY dan ICTR yang juga menerapkan hukum berkekuatan surut dalam penuntutan dan penjatuhan hukuman terhadap para pelaku kejahatan HAM, hal mana penjatuhan hukuman dimaksudkan untuk mematahkan impunitas. Pembentukan kedua
Mahkamah Pidana Internasional Ad Hoc tersebut berdasarkan tempus delicti-nya yakni setelah terjadinya peristiwa, namun yurisdiksi kedua mahkamah tersebut pada dasarnya terhadap perbuatan-perbuatan yang sebelumnya sudah merupakan kejahatan yang diakui menurut prinsip umum hukum internasional.

Berlakunya hukum secara retroaktif dalam Undang-undang Pengadilan HAM mengacu pula pada pertimbangan, bahwa terhadap pelanggaran HAM berat apabila diterapkan secara surut dianggap tidak melanggar standar asas legalitas dalam hukum pidana internasional, sebab kejahatan tersebut hanyalah perluasan yurisdiksi (jursidiction extention) dari kejahatan perang (an outgrowth of war crimes) yang telah diterima sebagai hukum kebiasaan internasional (international customary law) dan diputuskan oleh pengadilan internasional yang bersifat ad hoc. Praktek peradilan-peradilan pada sejumlah mahkamah tersebut memberikan paradigma dalam perkembangan hukum yang bergeser yakni, adanya pandangan yang semula berpegang teguh pada nullum crimen sine lege menjadi nullum crimen sine iure (tiada kejahatan tanpa penghukuman). ${ }^{70}$

Prinsip tersebut menjadi pedoman, bahwa setiap perbuatan yang merupakan bentuk kejahatan internasional tetap dapat dihukum walaupun belum ada hukum yang mengaturnya, karena menjadi tidak adil ketika yang bersalah tidak dapat dihukum dan dibiarkan bebas (unpunished). Dengan preseden peradilan IMT Nuremberg dan IMTFE Tokyo yang mengawali pengecualian atas asas legalitas, diikuti pembentukan ICTY dan ICTR hingga kasus Eichman di pengadilan distrik Yerussalem menunjukkan asas non-retroaktif dapat disimpangi demi tegaknya keadilan. ${ }^{71}$

Eksepsi para terdakwa yang menyatakan Pasal 4 jo Pasal 43 UU RI No. 26 Tahun 2000

${ }^{70}$ Machteld Boot, Nullum Crimen Sine Lege and the Subject Matter Jurisdiction of the International Criminal Court: Genocide, Crimes Against Humanity, War Crimes, School of Human Rights Research Series, Vol. 12, sebagaimana dikutip Zainal Abidin, Op. Cit, hlm. 7.

$$
{ }^{71} \text { Ibid. }
$$


bertentangan dengan nullum crimen sine lege, sesungguhnya adalah tidak tepat. Seperti yang tercantum dalam Penjelasan Pasal 4 UU No. 39 Tahun 1999 dan dalam Penjelasan Umum UU No. 26 Tahun 2000, yang menyebutkan mengenai pelanggaran hak asasi manusia yang berat seperti genosida dan kejahatan terhadap kemanusiaan, dapat digunakan hukum berkekuatan surut berdasarkan hukum internasional. Hal ini karena kejahatankejahatan tersebut adalah kontra terhadap hak yang paling hakiki yakni hak untuk hidup. Sebagaimana juga yang disebutkan dalam konstitusi bahwa asas non-retroaktif yang terdapat dalam Pasal 28I Ayat (1) tidaklah berlaku mutlak, sebab keberadaannya dibatasi oleh Pasal 28J Ayat (2). Hal ini sebagaimana juga yang diputuskan Mahkamah Konstitusi (MK) terhadap Perkara No. 065/PUU-II/2004 dalam Perkara Uji materiil ketentuan Pasal 43 Ayat (1) UU No. 26 Tahun 2000 yang dimohonkan oleh Abilio Jose Soares karena dianggap bertentangan dengan Pasal 28I Ayat (1) UUD 1945 Amandemen Kedua yang justru menganut asas non-retroaktif.

Terhadap perkara tersebut, Majelis Hakim MK memberikan beberapa pertimbangan diantaranya, bahwa Pasal 28I Ayat (1) UUD 1945 tidak boleh dibaca secara berdiri sendiri melainkan harus dibaca bersama-sama dengan Pasal 28J Ayat (2). Dengan cara demikian maka tampaklah bahwa hak untuk tidak dituntut berdasarkan hukum yang berlaku surut (nonretroaktif) tidaklah bersifat mutlak, sehingga dalam rangka "memenuhi tuntutan yang adil sesuai dengan pertimbangan moral, nilai-nilai agama, keamanan, dan ketertiban", dapat dikesampingkan. Tatkala tuntutan untuk menegakkan perikemanusiaan dan perikeadilan itu terhalang oleh asas non-retroaktif - yang secara historis pada awalnya dilatarbelakangi oleh maksud melindungi kepentingan manusia sebagai individu dari kesewenang-wenangan penguasa absolut - maka pengesampingan asas non-retroaktif dimaksud adalah tindakan yang tak dapat dihindari karena kepentingan yang hendak diselamatkan melalui tindakan pengesampingan itu adalah kepentingan kemanusiaan manusia secara keseluruhan yang nilainya melebihi kepentingan manusia sebagai individu. $^{72}$

Pertimbangan lainnya dari majelis hakim, bahwa ukuran untuk menentukan keseimbangan kepastian hukum dan keadilan, khususnya dalam menegakkan asas non-retroaktif harus dilakukan dengan mempertimbangkan tiga tugas/tujuan hukum yang senantiasa saling tarik-menarik (spannungsverhältnis) yaitu kepastian hukum (rechtssicherkeit), keadilan hukum (gerechtigkeit), dan kebergunaan hukum (zweckmassigkeit). Dengan mempertimbangkan ketiga tujuan hukum tersebut secara seimbang maka pemberlakuan hukum secara retroaktif yang terbatas, terutama terhadap kejahatan yang luar biasa (extraordinary crimes), secara hukum dapat dibenarkan. ${ }^{73}$

Pertimbangan hakim yang lebih menitikberatkan pada aspek keadilan daripada aspek kepastian hukum yang mendasari berlakukannya asas retroaktif, kiranya hal ini sesuai dengan teori yang dikemukakan Gustav Radbruch (Radbruch's formula) di Jerman pada saat pengadilan Nuremberg berlangsung, bahwa hukum positif dianggap sebagai lawan dari keadilan dan tidaklah dapat diterapkan jika ada ketidakkonsistenan antara undang-undang dan keadilan maka yang lebih didahulukan adalah keadilan. Formula Radbruch telah diterima secara luas dalam literatur hukum Jerman. ${ }^{74}$

Romli Atmasasmita berpendapat bahwa, perbedaan penerapan asas tersebut (nonretroaktif) tergantung dari sudut pandang mana, apakah sudut pandang aliran hukum alam dan utilitarian atau sudut pandang positivist. Dalam sudut pandang positivist, asas non retroaktif termasuk dalam hukum materiel (hukum substantif) sehingga sifat asas tersebut, "nonderogable" (tidak dapat disimpangi). Sedangkan menurut sudut pandang aliran hukum alam dan utilitarian, memandang asas non-retroaktif termasuk hukum prosedural (hukum acara)

72 Dirangkum dari Putusan Mahkamah Konstitusi Perkara No. 065/PUU-II/2004.

${ }^{73}$ Ibid.

74 Lihat Antonio Cassese, International Criminal Law, Oxford University Press, 2003, hlm. 143, dikutip dalam Eddy O.S. Hiariej,Op. Cit, hlm. 64. 
sehingga sifat asas tersebut, "derogable" (dapat disimpangi). ${ }^{75}$

Berpijak dari apa yang telah diuraikan di atas, menjadi jelas kenapa kemudian asas nonretroaktif dapat disimpangi pelaksanaannya. Dalam keadaan tertentu seperti halnya kepentingan kolektif bagi masyarakat, bangsa, maupun negara yang selama ini kurang mendapat perlindungan dari azas legalitas, maka pemberlakuan hukum pidana secara retroaktif kiranya dapat diterima guna memenuhi tuntutan moral pembalasan masyarakat. ${ }^{76} \mathrm{Hal}$ ini untuk menegaskan kembali bahwa sampai kapanpun terhadap pelaku pelanggaran HAM berat tetap harus dimintakan pertanggungjawabannya. Karenanya penerapan secara surut suatu ketentuan pidana adalah relevan dalam konteks perkara pelanggaran HAM berat.

\section{Penutup}

Kesimpulan

1. Putusan IMT Nuremberg dan IMTFE Tokyo yang kemudian diikuti oleh putusan Mahkamah Ad Hoc lainnya seperti ICTY dan ICTR merupakan preseden diterapkannya asas retroaktif terhadap kejahatan-kejahatan yang dikategorikan pelanggaran HAM berat sebagai kejahatan berdasarkan prinsip-prinsip hukum umum yang diakui oleh masyarakat internasional. Pertimbangan-pertimbangan dalam sejumlah mahkamah tersebut menunjukkan, bahwa aspek keadilan menjadi salah-satu landasan terpenting diterapkannya hukum secara retroaktif. Sebab, meskipun kejahatankejahatan yang dilakukan belum ada pengaturannya dalam bentuk hukum tertulis akan tetapi pelaku kejahatan tidak dapat

75 Romli Atmasasmita, Hukum Pidana Internasional dalam Kerangka Perdamaian dan Keamanan Internasional, Fikahati Aneska, Jakarta, 2010, hlm. 102-103.

${ }^{76}$ Yudha Bhakti, et., al, Laporan Akhir Tim Kompilasi Bidang Hukum Tentang Asas Retroaktif,http://www.tu.bphn.go.id/substantif/Data/ ISI\%20KEGIATAN\%20TAHUN\%202006/14kompi lasiASAS\%20RETROTIKAA.pdf, hlm.16. melepaskan diri begitu saja tanpa adanya penjatuhan hukuman, sehingga hanya dengan melakukan penghukuman terhadap pelaku kejahatan, maka keadilan dapat ditegakkan.

2. Beberapa kriterium yang dapat dipergunakan sebagai tolok ukur disimpanginya asas non-retroaktif dalam perkara pelanggaran HAM berat di Indonesia, yaitu: (a) untuk melindungi hak asasi manusia itu sendiri berdasarkan Pasal 28J Ayat (2) UUD 1945; (b) untuk mematahkan impunitas; (c) didasarkan atas prinsip keadilan bagi semua (the principle of justice for all), terutama terhadap korban kolektif tindak pidana dan sekaligus untuk memenuhi tuntutan moral pembalasan masyarakat (society retribution) terhadap pelaku kejahatan; (d) sebagai penyeimbang asas legalitas yang hanya mengutamakan kepastian hukum; (e) untuk mencegah tindak pidana dan sebagai efek jera bagi pelaku; (f) diberlakukan secara khusus, tertentu dan limitatif dengan locus dan tempus delicti yang jelas terhadap kejahatan genosida dan kejahatan terhadap kemanusiaan yang dikategorikan sebagai pelanggaran HAM berat; (g) didasari karena pelanggaran HAM berat memiliki karakteristik tindak pidana yang berbeda dengan yang ada di dalam KUHP; (h) besarnya kepentingan masyarakat umum secara kolektifitas yang harus dilindungi, serta bobot dan sifat (nature) hak-hak yang terlanggar akibat pemberlakuan undangundang demikian lebih kecil dari kepentingan masyarakat umum yang terlanggar; (i) tidak meletakkan asas lex talionis dan political revenge sebagai dasar penerapan undang-undang tersebut, melainkan pada upaya perlindungan dan penegakan terhadap hak-hak asasi manusia; dan (j) sebagai bentuk pertanggungjawaban negara atas pemenuhan kewajiban hukum internasional (primary rules and obligation).

\section{Saran}

1. Perlu dilakukan penyesuaian kembali terhadap UU No. 26 Tahun 2000 dalam menerapkan asas retroaktif yang hanya 
terbatas pada dua jenis kejahatan yang dikategorikan sebagai pelanggaran HAM berat yakni kejahatan genosida dan kejahatan terhadap kemanusiaan. Seyogyanya mencakup pula kejahatan perang sebagaimana yang diatur dalam berbagai Statuta Mahkamah Pidana Internasional.

2. Hak untuk tidak dituntut atas dasar hukum yang berlaku surut dalam Pasal 28I Ayat (1) UUD 1945 dan Pasal 4 UU No. 39 Tahun 1999 yang justru inkonsistensi dengan bagian penjelasannya, harus diubah dengan rumusan yang pada prinsipnya menyatakan bahwa hak untuk tidak dituntut atas dasar hukum yang berlaku surut dapat dibatasi (derogable) pelaksanaannya, yaitu dengan menerapkan asas retroaktif terhadap perkara pelanggaran HAM berat yang didasarkan pada beberapa kriterium sebagaimana yang telah disebutkan di atas. Selanjutnya, patut pula disempurnakan penggunaan istilah pelanggaran HAM berat yang tumpang tindih antara Pasal 104 UU No. 39 Tahun 1999 dengan Pasal 7 UU No. 26 Tahun 2000.

\section{DAFTAR PUSTAKA}

Buku:

Adnan Buyung Nasution dan A. Patra M. Zen, Instrumen Internasional Pokok Hak Asasi Manusia, Yayasan Obor Indonesia, Jakarta, 2006.

Andrey Sujatmoko, Tanggung Jawab Negara atas Pelanggaran Berat HAM, Grasindo, Jakarta, 2005.

Arie Siswanto, Yurisdiksi Material Mahkamah Kejahatan Internasional, Ghalia Indonesia, Bogor, 2005.

Bagir Manan,et.al.,Perkembangan Pemikiran dan Pengaturan Hak Asasi Manusia di Indonesia, Alumni, Bandung, 2006.

Binsar Gultom, Pelanggaran HAM dalam Hukum Keadaan Darurat di Indonesia, Gramedia Pustaka Utama, Jakarta, 2010.

Boer Mauna, Hukum Internasional: Pengertian Peranan dan Fungsi Dalam Era
Dinamika Global, Edisi ke-2, Alumni, Bandung, 2005.

Eddy Djunaedi Karnasudirdja, dari Pengadilan Militer Internasional Nuremberg ke Pengadilan HakAsasi Manusia, Tatanusa, Jakarta, 2003.

Eddy O.S. Hiariej, Pengadilan atas Beberapa Kejahatan Serius terhadap HAM, Erlangga, Jakarta, 2010.

Geoffrey Robertson Q.C., Kejahatan Terhadap Kemanusiaan: Perjuangan Untuk Mewujudkan Keadilan Global, Komnas HAM, Jakarta, 2002.

I Wayan Parthiana, Hukum Pidana Internasional dan Ekstradisi, Yrama Widya, Bandung, 2004.

Mahrus Ali dan Syarif Nurhidayat, Penyelesaian Pelanggaran HAM Berat: In Court System \& Out Court System, Gramata Publishing, Jakarta, 2011.

Mochtar Kusumaatmadja, Pengantar Hukum Internasional, Bandung, Binacipta, 1976.

Romli Atmasasmita, Pengantar Hukum Pidana Internasional Bagian II, Hecca Mitra Utama, Jakarta, 2004.

Internasional
Perdamaiandan dalam
Internasional, Fikahati Aneamanan
2010.

Titon Slamet Kurnia, Reparasi Terhadap Korban Pelanggaran HAM di Indonesia, Citra Aditya Bakti, Bandung, 2005.

Todung Mulya Lubis, Jalan Panjang Hak Asasi Manusia, Gramedia Pustaka, Jakarta, 2005.

Usman Hamid, et.al, Menatap Wajah Korban, Upaya Mendorong Penyelesaian Hukum Kejahatan Terhadap Kemanusiaan dalam Peristiwa Kerusuhan Mei 1998, TIFA, Jakarta, 2005.

Yudha Bhakti Ardhiwisastra, Hukum Internasional; Bunga Rampai, Alumni, Bandung, 2003.

\section{Sumber Lain:}

Agustinus Supriyanto, Urgensi Memahami Beberapa Aspek Hukum Internasional Dalam Mengamandemen Pasal-Pasal 
Tertentu UUD 1945, Jurnal Mimbar Hukum, Volume X, No. 36, 2000.

Agus Raharjo, Problematika Asas Retroaktif Dalam Hukum Pidana Indonesia, melalui,http://fh.unsoed.ac.id/sites/defau 1t/files/VOL8J2008\%20AGUS\%2 0RAHARJO.pdf

Agung Yudhawiranata, Analisa Kritis Terhadap Pengadilan HAM Internasional, melalui,http://pusham.uii.ac.id/upl/articl e/id Berkaca\%20Pada\%20Tokyo $\% 20$ dan $\% 20$ Nuremberg.pdf

ELSAM, Mendorong Pembentukan Kembali UU Komisi Kebenaran dan Rekonsiliasi: Pandangan ELSAM Mengenai Pentingnya RUU Komisi Kebenaran dan Rekonsiliasi,

http://www.elsam.or.id/downloads/1301 382601_Brief_Paper_Mendorong Pembentukan_Kembali_UU_KKR.pdf,

-------, Progres Report IX, Pemantauan Pengadilan HAM Ad Hoc Perkara Pelanggaran HAM Berat di TimorTimur: Kejahatan Terhadap Kemanusiaan Tanpa Penanggung Jawab, Jakarta, 20 Desember2002,

melalui,http://www.elsam.or.id/downloa ds/1268376446 Progress Report Pengadi lan Timor Timur 9.pdf

-------, Preliminary Conclusive Report Pengadilan HAM Kasus Tanjung Priok, http://www.elsam.or.id/downloads/1316 576901 04. Preliminary Conclusive Rep ort 123.pdf

Ifdhal Kasim, et, al, Pencarian Keadilan di Masa Transisi, http://www.elsam.or.id/downloads/1296 551052 Pencarian Keadilan di Masa Tr ans isi.pdf

Indria Fernida, Hak Asasi Manusia, Akuntabilitas dan Penegakan Hukum di Indonesia: Sebuah Toolkit, Insitute for Defense, Security and Peace Studies Press, Jakarta, 2009,melalui,http://www.dcaf.ch/content /download/35686/526589/file/8.\%20Hum an $\% 20$ Rights $\% 20$ and $\% 20$ SSR.pdf

Kompas, Kasus Talangsari 22 Tahun Menggantung, 8 Februari 2011
Muladi, Mekanisme Domestik untuk Mengadili Pelanggaran HAM Berat Melalui Sistem Pengadilan atas Dasar UU RI No. 26 Tahun 2000, Seri Bahan Bacaan Kursus HAM untuk Pengacara X, Tahun 2005, http://www.elsam.or.id/pdf/kursusham/ Mekanisme_UU_26_2000.pdf

http://www.tempo.co/read/news/2003/10/08/055 20560/Pembela-Peristiwa-Priok-BukanTanggung-Jawab-Dandim, 8 Oktober 2003.

http://www.pusakaindonesia.org/pancasilamemayungi-hak-asasi-manusia-ham/

Putusan Mahkamah Konstitusi Perkara No. 065/PUU-II/2004.

Yudha Bhakti, et., al, Laporan Akhir Tim Kompilasi Bidang Hukum Tentang Asas Retroaktif,http://www.tu.bphn.go.id/subs tantif/Data/ISI\%20KEGIATAN\%20TAH $\underline{\mathrm{UN}}$ \%202006/14kompilasiASAS\%20RETR OTIKAA.pdf

Zainal Abidin, Pengadilan Hak Asasi Manusia di Indonesia: Regulasi, Penerapan dan Perkembangannya, Makalah yang disampaikan pada Kursus HAM untuk Pengacara ke XIV, diselenggarakan oleh ELSAM, Jakarta, 2010, http://www.elsam.or.id/downloads/1290 394945_Paper_Pengadilan_HAM _untuk_Kursus_HAM.pdf.

\section{Perundang-undangan:}

Undang-Undang Dasar 1945.

Undang-undang Republik Indonesia Nomor 39 Tahun 1999.

Undang-undang Republik Indonesia Nomor 26 Tahun 2000.

Charter of the International Military TribunalNuremberg (IMT).

Charter of the International Military Tribunal for The Far East-Tokyo (IMTFE).

Charter of the United Nations.

Statute of the International Tribunal for Rwanda

Statute of the International Tribunal for the former Yugoslavia.

The Universal Declaration of Human Rights (UDHR) 1948 
Jurnal Civic Education, Vol. 1 No. 2 Desember 2017

The International Covenant on Civil and Political Rights (1966). 